\title{
AKRUAL
}

Jurnal Akuntansi

http://fe.unesa.ac.id/ojs/index.php/akrl

\section{MEMBANGUN HUMAN CAPITAL MELALUI KEPEMIMPINAN DAN KOMITMEN ORGANISASI}

\author{
Moh Nasih \\ Fakultas Ekonomi dan Bisnis Universitas Airlangga \\ Email: mhnasih@yahoo.com \\ Artikel diterima: 2 Nopember 2010 \\ Terakhir direvisi: 6 Maret 2011
}

\begin{abstract}
Every company is constructed through two kinds of capital, which is financial capital and intellectual capital. If the company's capital is described as a tree, the human capital, an essential part of intellectual capital, is the resin. Resin allows the tree grows, and only the human capital that enables organizations to grow and develop. Considering the strategic position of human capital, it is a compulsion for a company to develop it. The problem is how to build human capital effectively? This study aimed to identify the factors that determine the development of human capital in an organization. There are 2 (two) major factors that hypothetically influence human capital, which is leadership and organizational commitment. Leadership does not directly affect human capital. Leadership influence human capital through organizational commitment. In other words, organizational commitment is an intervening variable for the relationship or the influence of leadership on human capital. This hypothesis is based on a 'fact' that the function of leadership is oriented and intended to obtain or build the commitment of each personnel. Only committed personnel will provide their best for the organization. Only through the best contributions of every personnel, human capital can be built and developed. Leadership is useless if it can not obtain and create commitment. Personnel are useless, no matter how many and how skilfull they are, if they do not contribute the best for the organization. The presence of personnel without their comitment will be the same with their absence; even they may actually be detrimental to the organization.
\end{abstract}

Keywords: Human capital, leadership, organizational commitment.

\section{PENDAHULUAN}

\section{Latar Belakang}

Setiap organisasi atau perusahaan dibangun dengan sekurang-kurangnya 2 pilar atau modal yakni financial capital dan intellectual capital. Financial capital melekat pada aset fisik organisasi dan telah lama menjadi obyek analisis akademisi. Bahkan, adalah financial capital yang menjadi cikal bakal ilmu akuntansi yang sering didifinisikan sebagai ilmu, pengetahuan, seni, teknologi, atau proses pengkomunikasian informasi keuangan suatu entitas kepada pengguna seperti pemegang saham dan manajemen. Akuntansi didefinisikan oleh American 
Institute of Certified Public Accountants (AICPA) sebagai "the art of recording, classifying, and summarizing in a significant manner and in terms of money, transactions and events which are, in part at least, of financial character, and interpreting the results thereof."

Pilar kedua bangunan organisasi atau perusahaan adalah intellectual capital (IC), yang karena relatif masih baru, belum ada satu definisi yang definitif tentangnya. Bahkan, untuk merujuk pada pengertian yang serupa, telah digunakan istilah yang berbeda-beda, seperti intellectual capital, virtual capital, organizational capital, intellectual assets, intangible resources, dan intangible asset. Stewart (1997: x) menyebutnya sebagai intellectual capital dan mendefinisikannya dengan satu kalimat sebagai materi intelektual seperti pengetahuan, informasi, hak kepemilikan intelektual, dan pengalaman yang dapat digunakan untuk menciptakan kekayaan. Pakar lain juga sering menyebutnya sebagai modal intelektual yang didefinisikan sebagai keseluruhan intelek yang dimiliki anggota perusahaan, yang terbentuk dari keseluruhan pengetahuan, keterampilan, kemampuan, pengalaman profesional, dan pemahaman kontekstual dari anggota perusahaan tersebut. Nahapiet dan Ghoshal (1998: 245), berdasarkan fungsinya, menyebut IC sebagai a valuable resource and a capability for action based in knowledge and knowing. Sedangkan Klein dan Prusak, sebagaimana dikutip oleh Stewart (1997: 67) mendefinisikan IC sebagai materi intelektual yang telah diformalisasi, ditangkap, dan dimanfaatkan sehingga perusahaan mempunyai aset yang nilainya lebih tinggi.

Intellectual capital merupakan akumulasi pengetahuan, keahlian, kemampuan, dan ketrampilan yang tertanam dalam otak manusia yang menjadi sumber inovasi, regenerasi, dan dapat digunakan untuk menciptakan keunggulan diferensial. Dalam batas tertentu, IC didapat dengan memperoleh dan mengembangkan pekerja yang tepat (Olve, Roy, dan Wetter; 1999: 27) melalui pengembangan komitmen dan kompetensi (Ulrich, 1998: 15) sehingga operasi organisasi dapat dijalankan secara lebih berdaya guna dan berhasil guna.

\section{KAJIAN PUSTAKA \\ Human Capital}

Taksonomi yang banyak digunakan untuk menggambarkan IC adalah taksonomi yang dikembangkan oleh Edvinsson dan Malone (1997), dan Sveiby (1997) yang secara umum mengindikasikan bahwa IC merupakan penjumlahan setiap komponen-komponenya yakni human capital/individual competence; structural capital/ external dan internal structure; dan customer capital/relational capital. IC merupakan persamaan identitas atau persamaan aritmatika dan dapat dihitung dengan menjumlahkan Human Capital (HC), Structural Capital (SC), Customers Capital (CC). Secara matematis, $\mathrm{IC}=\mathrm{HC}+\mathrm{SC}+\mathrm{CC}$. Intellectual capital is the arithmatic mean of all the capital components in play (Edvinsson dan Malone, 1997: 187).

Human capital adalah kekayaan perusahaan yang tersimpan pada diri setiap personil dalam segala aspeknya (human factor). Keberadaan manusia dalam perusahaan merupakan suatu keniscayaan sebab organisasi merupakan kesatuan sosial yang terdiri dari orang-orang atau sekelompok orang yang saling berinteraksi (Robbin, 1990: 4). Manusia (human) merupakan faktor penting 
karena merupakan sumber ide yang sangat berharga bagi perusahaan. Personil adalah tempat di mana semua tangga dimulai. Bila IC adalah sebuah pohon, maka personil adalah getah yang membuat perusahaan tumbuh. Uang dapat berbicara tetapi tidak dapat berpikir. Mesin mungkin dapat melaksanakan pekerjaan dengan lebih baik daripada manusia tetapi ia tidak dapat menciptakan (Stewart, 1997: 90).

Personil merupakan sumberdaya kritis bagi perusahaan karena kemampuannya untuk mengungkit, mendirect, mengelola, dan mentransformasikan sumberdaya uang dan fisik (financial capital) untuk menciptakan nilai dan selanjutnya keuntungan bagi perusahaan. Personil merupakan infrastruktur sumber inovasi (learning and growth) yang memungkinkan perusahaan untuk mampu melakukan operasi utama (dalam value chain) secara optimal dan menghasilkan margin (Porter, 1993: 33); mempunyai proses bisnis internal yang efisien, memuaskan dan meningkatkan loyalitas customer serta akhirnya memperoleh ROCE yang tinggi (Kaplan dan Norton, 1996: 127). Menurut Teece (Walker, 2001: 1-2):

employees in a firm create the idiosyncratic capabilities and competitive advantages that are reflected in firm performance and the market's evaluation of the firm. Competitive advantage based on human capital incorporates the complex structure and interactions of human and is much more dificult to imitate than the competitive advantege based upon physical and financial capital, therefore creating a sustainable competitive advantage.

Dalam diri setiap personil terdapat banyak dimensi yang mempengaruhi pola perilaku serta besar kecilnya kontribusi yang dapat diberikan kepada perusahaan. Dimensi tersebut secara umum dapat diklasifikasikan menjadi dimensi kuantitatif (tangible) yang lebih melihat jumlah personil yang terlibat dalam keseluruhan proses dan operasi perusahaan; serta dimensi kualitatif (intangible). Dimensi kualitas yang telah lama mendapatkan perhatian berbagai kalangan serta menjadi isu sentral berkaitan dengan bakat (aptitudes), dan kemampuan (abilities) personil adalah kompetensi (Schermerhorn, Hunt dan Orborn, 1995: 15; Kaplan dan Norton, 1996: 112). Aspek lain yang tidak kalah penting adalah komitmen personil yang merupakan kemauan personil untuk memberikan yang terbaik bagi perusahaan. Dari berbagai aspek intangible tersebut Ulrich (1998: 15) meringkas menjadi hanya dua aspek yakni kompetensi dan komitmen serta mengembangkan formula Intellectual capital $=$ Competence $x$ Commitment.

Kompetensi personil direpresentasikan dalam bentuk kemampuan individu-individu untuk melaksanakan keseluruan tugas yang diembankan kepadanya. Kompetensi merupakan kemampuan yang memungkinkan seseorang untuk meraih prestasi lebih pada satu atau lebih aspek pekerjaannya. Sama dengan kompetensi organisasi tetapi pada dataran dan unit analisis yang berbeda, kemampuan dan kompetensi personil meliputi 3 jenis kemampuan (Schermerhorn, Hunt and Orborn, 1995: 53), yakni:

a. Kemampuan untuk menerapkan pengetahuan atau keahlian yang dipunyai untuk menyelesaikan tugas dan misi yang diemban oleh masing-masing individu termasuk memilih metode, proses dan prosedur yang paling tepat. 
b. Kemampuan untuk bekerjasama secara baik yang didasarkan pada semangat saling percaya dan empati dalam hubungan antar personal organisasi.

c. Kemampuan untuk menganalisis dan memecahkan masalah-masalah yang kompleks yang lebih terfokus pada kapasitas mental individu untuk mengidentifikasi masalah dan peluang, untuk memperoleh dan menginterpretasikan informasi yang relevan dan mengambil keputusan individu.

Kompetensi seseorang merupakan dasar dari keahlian pribadi. Orang dengan keahlian pribadi yang tinggi berusaha secara terus-menerus untuk memperluas kemampuan dan menciptakan hasil sesuai dengan yang diharapkan. Apabila keahlian pribadi telah menjadi suatu disiplin, maka akan mendorong dilakukannya upaya secara terus-menerus untuk memperjelas apa yang sesungguhnya penting serta berusaha untuk terus menerus belajar bagaimana melihat realita saat ini secara lebih jelas dan tegas. Upaya terus-menerus tersebut, apabila dilakukan secara bersama-sama oleh anggota organisasi, akan melahirkan organisasi-belajar (learning organization) yang mempunyai kemampuan lebih untuk menghadapi tuntutan lingkungan yang semakin keras.

Kompetensi personil digambarkan oleh Kaplan dan Norton (1996: 127) mempunyai hubungan yang cukup kuat terhadap tingkat pembelajaran dan inovasi organisasi yang pada akhirnya berpengaruh pula pada kinerja organisasi. Kompetensi personil yang didukung oleh infrastruktur teknologi yang memadai dan iklim yang kondusif untuk beraksi akan berpengaruh terhadap kepuasan personil yang selanjutnya akan berpengaruh pada produktivitas dan retensi personil. Kompetensi personil merupakan pemungkin bagi peningkatan kualitas proses bisnis internal dalam bentuk kualitas proses dan process cycle-time. Dengan proses bisnis internal berkualitas, organisasi akan dapat melayani konsumennya dengan baik sehingga mendorong terciptanya loyalitas konsumen serta mendorong peningkatan ROCE.

Aspek personil lain yang bersifat intangible adalah komitmen yang merujuk pada tingkat keinginan dari para karyawan untuk tetap menjadi anggota organisasi dan melakukan yang terbaik bagi organisasi (Porter, et al., 1974: 12). Komitmen personil merefleksikan sifat dan kualitas keterkaitan antara personil dan organisasi. Komitmen merupakan proses dengan mana tujuan organisasi merupakan bagian tidak terpisahkan dan bahkan terintegrasi dengan tujuan individu. Porter et al. (1981: 21) juga menyatakan bahwa komitment organisasi adalah kekuatan relatif atas pengenalan individu-individu dengan keterlibatan dalam sebuah organisasi tertentu. Komitment organisasi merefleksikan keyakinan setiap personil tentang misi dan tujuan organisasi, keinginan untuk berkontribusi penuh dalam pencapaian tujuan tersebut, serta keinginan kuat untuk secara terus menerus bekerja pada organisasi. Komitmen organisasi merupakan the degree to which an employee identifies with a particular organization and its goals and wishes to maintain membership in the organization (Robbins and Judge, 2009: 113). Terdapat dua pendekatan dalam mengidentifikasi komitmen organisasi yakni attitudinal commitment dan behavioral commitment.

Attitudinal commitment berfokus pada proses bagaimana seseorang mulai memikirkan mengenai hubungannya dengan organisasi yang selanjutnya 
menentukan sikap dirinya terhadap organisasi. Komitmen jenis ini umumnya dimanifestasikan dalam bentuk kehadiran sebagai anggota organisasi, tidak berkeinginan pindah ke organisasi lain, serta produktivitas yang tinggi. Pada sisi lain, behavioral commitment berfokus pada proses di mana seseorang merasa terikat kepada organisasi tertentu dan bagaimana cara mengatasi setiap masalah yang dihadapi. Perilaku tertentu seseorang merupakan konsekuensi dan menifestasi dari komitmen seseorang pada organisasi di mana mereka bekerja. Seseorang yang mempunyai komitmen tinggi umumnya mempunyai pandangan lebih positif terhadap organisasi. Komitmen dapat berkembang secara retrospektif atau sebagai justifikasi terhadap tingkah laku yang sedang berlangsung juga secara prospektif atau berdasarkan persepsi dari kondisi saat ini atau di masa depan di dalam organisasi. Terdapat tiga dimensi komitmen organisasi menurut Allen and Meyer (1990), yakni affective yang merujuk pada muatan emosional pekerja untuk, identifikasi dengan, dan terlibat dalam organisasi; continuance yang merujuk pada komitmen berdasarkan pada resiko yang dinilai akan terjadi bila seseorang akan meninggalkan organisasi; dan normative yang merujuk pada perasaan seseorang atas tugas dan tanggungjawab yang harus diselesaikan melalui organisasi.

Komitmen organisasi merupakan aset tak ternilai bagi perusahaan untuk menjalankan misi dan meraih keuntungan optimal. Sesuai hakekatnya, komitmen yang tinggi, memungkinkan terciptanya:

a. Keserasian derap langkah semua bagian organisasi karena dilandasi motivasi yang sama yaitu kemajuan organisasi. Atribut yang sangat signifikan dari komitmen adalah kemampuannya untuk menyatukan tujuan individu dengan tujuan organisasi.

b. Memudahkan penyelesaian berbagai macam bentuk konflik yang timbul dalam organisasi, karena lebih mengutamakan kepentingan organisasi. Bila terjadi konflik kepentingan individu, maka segera dapat dinetralisasi dengan komitmen yang kuat terhadap tujuan organisasi.

c. Memperkuat tumbuhnya sinergi dalam perusahaan sehingga vitalitas organisasi tetap terjaga dengan baik. Komitmen yang nampak berhubungan sangat kuat dengan keinginan dan motivasi personil untuk tetap berada dalam organisasi, juga membawa akibat pada performansi jabatan. Dikaitkannya secara integratif tujuan individu dan tujuan organisasi sangat memungkinkan terbentuknya sinergi dalam organisasi.

d. Tumbuh berkembangya kreatifitas dan inovasi di segenap lapisan karyawan perusahaan, karena dilandasi motivasi yang kuat untuk mencapai kemajuan organisasi. Komitmen personil membutuhkan kebebasan bertindak yang besar, segala upaya dan aktivitasnya didorong oleh motivasi yang dalam.

Banyak faktor diduga mempengaruhi komitmen seseorang pada organisasi. Faktor tersebut bisa berasal dari dalam organisasi maupun dari luar organisasi. Menurut Greenberg and Baron (2003:133) terdapat 3 (tiga) metode untuk mengembangkan komitmen organisasi. Ketiga cara tersebut adalah, pertama, jobs enrichment atau pengayaan pekerjaan. Seseorang diidentifikasi akan mempunyai komitmen tinggi apabila yang bersangkutan mendapatkan kewenangan untuk mengelola suatu pekerjaan secara otonom dan pekerjaan tersebut merupakan pekerjaan penting serta memberikan kontribusi berarti bagi 
perusahaan. Kedua, menyelaraskan kepentingan perusahaan dan kepentingan karyawan. Organisasi (manajemen) dan pegawai umumnya mempunyai kepentingan yang berbeda. Oleh karena itu, setiap organisasi diharapkan selalu berusaha untuk mempertemukan kepentingan tersebut. Beberapa perusahaan melakukannya melalui mekanisme profit sharing plans. Ketiga, merekrut dan menyeleksi pegawai baru sesuai dengan kebutuhan nilai perusahaan. Dengan cara ini, hanya calon pegawai yang mempunyai nilai-nilai yang sepadan dengan nilainilai perusahaan yang dapat diterima.

\section{Komitmen Organisasi}

Komitmen berasal dari kata latin committere yang berarti menggabungkan, mempercayai dan mengerjakannya (Snyder, 1994;97). Organisasi adalah entitas sosial yang dibangun untuk mencapai tujuan tertentu, berisi posisi-posisi yang saling berinteraksi dan secara sengaja distrukturisasi dan dikoordinasikan, serta berada di dalam lingkungan sosial yang lebih besar (Bedeian, 1991:7). Dari definisi tersebut, organisasi berisikan kumpulan orang yang berinteraksi untuk mencapai tujuan tertentu dari organisasi. Komponen dari suatu organisasi antara lain meliputi manajer maupun pegawai dan pihak-pihak yang terkait yang berinteraksi dan terkoordinasi.

Perusahaan yang sukses adalah perusahaan yang paling mampu menarik, mengembangkan dan menjaga individu yang memiliki skill, perspektif, dan pengalaman yang cukup untuk menggerakkan bisnis global, untuk itu kekayaan intelektual diperlukan untuk menciptakan dan mendistribusikanproduk dan jasa ke bisnis global (Ulrich, 2000). Untuk mencapai kinerja perusahaan secara maksimal dan keunggulan kompetitif diperlukan sumber daya dan kapabilitas organisasi meliputi kemampuan untuk membentuk dan menjaga sumber daya manusia yang memiliki kapabilitasdan komitmen (Becker, et al.,2000). Terkait dengan hal tersebut, untuk mencapai tujuan organisasi dibutuhkan komitmrn organisasi dari sumber daya manusia terhadap apa yang dicapai organisasi termasuk didalamnya komimen organisasi.

Konsep dari komitmen organisasi didasarkan pada premis bahwa individuindividu membentuk suatu artachment pada organisasi (Ketchand \& Strawser, 1998:109). Komitmen organisasi Porter et al. (1974:604) didefinisikan sebagai:

"relative strength of on individual's identification with and involvement in a particular organization"

Menurut Aranya et al. (1981) dalam Poznanski dan Bline (1997:254), komitmen organisasi dapat didefinikan sebagai 1) keyakinan dan penerimaan tujuan dan nilai organisasi; 2) Kemauan untuk berusaha atau bekerja keras untuk kepentingan organisasi; 3) Hasrat untuk menjaga keanggotaan organisasi.

Beberapa penelitian di bidang akuntansi mengemukakan bahwa para manajer tingkat bawah mempunyai informasi yang lebih akurat daripada para atasannya mengenai kondisi-kondisi lokal pusat pertanggung-jawaban yang dipimpinnya. Penelitian ini didasarkan pada gagasan bahwa para manajer bawah (manajer pusat pertanggunjawaban) seringkali memiliki informasi yang lebih baik mengenai level anggaran yang diperlukan untuk mendukung pelaksanaan aktivitas-aktivitas unit organisasinya daripada atasannya (manajer puncak). Oleh karena itu, para manajer bawahan akan berusaha untuk memberikan informasi 
tersebut ke dalam usulan anggarannya untuk menjamin bahwa mereka memperoleh sumber-sumber yang mencukupi untuk melaksanakan aktivitasaktivitasnya

Komitmen organisasi yang kuat akan mendorong para manajer bawahan berusaha keras mencapai tujuan organisasi (Angel dan Perry,1981; Porter et al., 1974). Komitmen yang tinggi menjadikan individu lebih mementingkan organisasi daripada kepentingan pribadi dan berusaha menjadikan organisasi menjadi lebih baik. Komitmen organisasi yang rendah akan membuat individu untuk berbuat untuk kepentingan pribadinya. Selain itu, komitmen organisasi dapat merupakan alat bantu psikologis dalam menjalankan organisasinya untuk pencapaian kinerja yang diharapkan (Nouri dan Parker, 1996; McClurg, 1999; Chong dan Chong, 2002; Wentzel, 2002). Komitmen organisasi yang tinggi akan meningkatkan kinerja yang tinggi pula (Randall,1990) dalam Nouri dan Parker (1998).

Komitmen organisasi merupakan sebuah ekspresi dari keinginan seseorang untuk menunjukkan prilakunya. Pada saat seseorang komit terhadap organisasi, seseorang tersebut akan memiliki kecenderungan yang lebih tinggi untuk berperilaku berdasarkan norma institusional dibandingkan mereka yang tidak komit. Sebagai hasilnya, komitmen memperkuat keinginan seseorang untuk menunjukkan perilaku yang diinginkan oleh organisasi. Sebaliknya, komitmen yang rendah akan menghilangkan kecenderungan orang akan berperilaku sesuai dengan apa yang diinginkan organisasi. Komitmen organisasi merefleksikan kekuatan relatif dari sebuah indetifikasi individual seseorang dalam keterlibatannya didalam organisasi (Steers, 1977 dalam Randal 1987: 461). Komitmen organisasi dapat digambarkan dalam tiga komponen utama: (a) keyakinan yang kuat dari seseorang dan sebuah keyakinan terhadap tujuan organisasi; (b) keinginan seseorang untuk memberikan usaha yang sesuai untuk kepentingan organisasi; (c) hasrat yang jelas dari seseorang untuk memelihara keanggotaan (Randal, 1987:461). Semakin kuat komitmen organisasi seseorang, semakin kuat pula kecenderungan seseorang untuk diarahkan dalam tindakannya oleh standard internal yang ada.

Menurut Robbin (2003:94) komitmen pada organisasi merupakan suatu sikap kerja, didefinisikan sebagai keadaan dimana karyawan mengaitkan dirinya ke organisasi tertentu dan sasaran-sasarannya, serta berharap mempertahankan keanggotaan dalam organisasi itu. Menurut O’Reilley dalam Staw (1991: 299) komitmen terhadap organisasi adalah rasa keterikatan seseorang kepada organisasi, termasuk perasaan terlibat dalam pekerjaan, loyalitas, dan kepercayaan pada nilai-nilai organisasi.

Steers (1985: 50) mendefinisikan komitmen organisasi sebagai rasa identifikasi (kepercayaan terhadap nilai-nilai organisasi), keterlibatan (kesediaan untuk berusaha sebaik mungkin demi kepentingan organisasi) dan loyalitas (keinginan untuk tetap menjadi anggota organisasi yang bersangkutan) yang dinyatakan oleh seorang pegawai terhadap organisasinya. Steers berpendapat bahwa komitmen organisasi merupakan kondisi dimana pegawai sangat tertarik terhadap tujuan, nilai-nilai, dan sasaran organisasinya. Komitmen terhadap organisasi artinya lebih dari sekedar keanggotaan formal, karena meliputi sikap menyukai organisasi dan kesediaan untuk mengusahakan tingkat upaya yang 
tinggi bagi kepentingan organisasi demi pencapaian tujuan. Berdasarkan definisi ini, dalam komitmen organisasi tercakup unsur loyalitas terhadap organisasi, keterlibatan dalam pekerjaan, dan identifikasi terhadap nilai-nilai dan tujuan organisasi

Menurut Kwon (2002) literatur yang membahas komitmen organisasi secara tradisional memisahkan antara komitmen attitudial dengan komitmen behavioral, meskipun dijumpai adanya hubungan yang resiprokal antara keduanya. Komitmen attitudial adalah sikap keterikatan individu dan identifikasinya dengan tujuan dan nilai-nilai suatu organisasi. Berbeda dengan komitmen attitudial, komitmen behavioral membahas tentang proses dimana suatu sikap individual di masa lalu mengikatnya dengan organisasi. Salancik dalam Kwon (2002) menyatakan bahwa komitmen organisasi didefinisikan sebagai suatu keadaan dimana seorang individu menjadi terikat atas apa yang dilakukan dan, melalui kegiatan tersebut, untuk kepercayaan yang mempertahankan kegiatan dan keterlibatannya. Pendekatan behavioral memandang komitmen sebagai kecenderungan untuk menjalankan secara konsisten suatu aktivitas karena adanya biaya apabila melakukan sebaliknya. Dalam definisi ini, kegiatan untuk tetap terlibat dengan organisasi, dan timbulnya biaya diasosiasikan dengan menghentikan kegiatan, meninggalkan, dan mencari tempat baru.

Komitmen Organisasi didefinisikan sebagai keyakinan dan dukungan yang kuat terhadap nilai dan sasaran yang ingin dicapai organisasi. Komitmen organisasi dapat didefinisikan sebagai "relative strength of an individual's identification with and involvement in a particular organization" (Porter, et.all, 1998: 109). Aranya et.all dalam Poznanski dan Blinc (1997: 254) mendefinisikan komitmen sebagai :

1. Keyakinan dan penerimaan tujuan dan nilai organisasi.

2. Kemauan untuk berusaha atau bekerja untuk kepentingan organisasi.

3. Hasrat untuk menjaga keanggotaan organisasi.

Komitmen organisasi dibangun melalui identifikasi individual dengan tujuan organisasi (affective commitment) dan biaya terkait dengan tetap tinggalnya seseorang pada suatu organisasi (the "side-bet" theory atau continuance commitment) serta apa yang sebaiknya dilakukan (normatif commitment) (Meyer, 1990: 1). Hackket et.all, (1994) mengatakan bahwa individu yang memiliki komitmen organisasi yang merupakan affective commitment melaksanakan perannya karena hasrat yang ingin dilakukan. Hasrat ini berdasarkan identifikasinya pada organisasi dan keinginannya untuk membantu organisasi mencapai tujuan (Strawser dan Ketchand, 1998: 111). Individu yang memiliki bentuk komitmen organisasi berupa continuance commitment berdasarkan Becker's (1960) mengenai side-bets theory individu tetap bekerja untuk organisasi mereka mengakumulasi benefit yang lebih tinggi daripada mereka mencari

Berdasarkan pandangan dikotomis antara komitmen behavioral dengan attitudial, Meyer and Allen dalam Kwon (2002) membuat konseptualisasi komitmen sebagai kontruk multidimensional. Konstruk multidimensional tentang komitmen terdiri tiga komponen komitmen yakni afektif, kontinuans, dan normatif yang merupakan integrasi antara komitmen attitudial dan behavioral. Allen and Meyer dalam Robbins (2003. 300 ) menyatakan terdapat tiga dimensi 
komitmen organisasi yakni komitmen afektif, komitmen normatif dan komitmen kontinuans.

1. Komitmen afektif adalah komitmen yang berkaitan dengan emosional, identifikasi dan keterlibatan pegawai di dalam suatu organisasi. Dalam hal ini individu menetap dalam suatu organisasi karena keinginannya sendiri.

2. Komitmen normatif adalah suatu perasaan akan suatu tanggung jawab atau kewajiban terhadap organisasi. Individu tetap tinggal pada suatu organisasi karena merasa wajib untuk loyal kepada organisasi tersebut.

3. Komitmen kontinuans adalah perasaan bahwa biaya untuk meninggalkan jauh lebih mahal, atau berdasarkan persepsi pegawai tentang kerugian yang akan dihadapinya jika ia meninggalkan organisasi. Individu memutuskan untuk menetap pada suatu organisasi karena menganggap hal tersebut sebagai suatu pemenuhan kebutuhan.

\section{Komitmen Afektif ((Affective Commitment).}

Komitmen Afektif merupakan dimensi dari komitmen organisasi yang lebih menekankan pada emosional individu. Pada dimensi komitmen organisasi ini, anggota organisasi tertarik lebih masuk organisasi atau perusahaan disebabkan oleh dorongan afektifnya daripada kognitifnya. Pada dimensi komitmen afektif ini, anggota organisasi memilih organisasi lebih disebabkan adanya dedikasi yang tinggi agar perusahaan menjadi berkembang. Dimensi ini biasanya tumbuh subur pada perusahaan organisasi dengan adanya kesamaan sikap, dengan kepercayaan yang kuat dalam penerimaan tujuan dan nilai-nilai organisasi (identification), kemauan untuk mengerahkan usahanya atas nama organisasi (involvement), dan keinginan yang kuat untuk tetap bersama organisasi (loyalty) didorong adanya kesamaan sikap yang lebih diwarnai oleh faktor afektif anggota organisasi. Riggio dalam Regnyowijoyo (2003) menyatakan bahwa para pekerja yang mempunyai perasaan positif tentang seluruh pekerjaan organisasi kelihatannya lebih sedikit absennya dalam bekerja dan tidak mau meninggalkan organisasi untuk bekerja pada yang lain dibandingkan hal yang sama jika pekerja mempunyai tingkah laku negatif terhadap organisasi.

\section{Komitmen Kontinuans (Continuance Commitment)}

Pada dimensi komitmen organisasi ini, komitmen kontinuan adalah berbeda dengan komitmen afektif. Komitmen kontinuan menunjukkan komitmen anggota organisasi lebih disebabkan biaya hidup. Dengan demikian, semakin besar perolehan pendapatan karyawan dari perusahaan maka akan semakin besar kepuasan kerja, prestasi kerja (performance), dan sebaliknya akan semakin kecil kemangkiran dan intensiti turn-over. Tetapi secara prinsip baik dimensi komitmen afektif maupun komitmen kontinuan, komitmen organisasi yang baik dan jelas sangat penting artinya, sebab sebagaimana komitmen organisasi berhubungan dengan tingkah laku dari berhenti bekerja berkorelasi secara negatif. Oleh sebab itu sangat beralasan jika komitmen organisasi cukup mempengaruhi prestasi kerja karyawan. 


\section{Komitmen Normatif ( Normative Commitment)}

Komponen normatif dari komitmen ditekankan pada perasaan loyalitas terhadap organisasi tertentu yang terbentuk dari pendalaman tekanantekanan normatif yang mendesak dari seseorang. Dalam penerimaan pengaruh oleh seseorang di dalam organisasi, pendalaman terjadi saat nilai-nilai yang tertanam dalam diri seseorang dan grup atau organisasi adalah sama. Sebagai akibat persamaan nilai tersebut, seseorang akan melakukan tingkah laku yang komit karena mereka percaya bahwa hal itu merupakan hak mereka dan hal yang baik untuk dilakukan (Allen and Meyer, 1991).

Pola pikir ini konsisten dengan pandangan beberapa penulis yang menyatakan bahwa norma-norma pribadi (didefinisikan sebagai kewajiban moral dalam diri) adalah merupakan faktor utama terhadap perilaku, termasuk menjadikan organisasi tersebut sebagai pilihan untuk bekerja. Allen and Meyer (1991) menyebutkan definisi komitmen normatif (yang dikenal sebagai komitmen moral) yang membedakannya dari komponen komitmen afektif dan komitmen kontinuan. Mereka mendefinisikan komitmen normatif sebagai suatu tingkatan dimana seseorang terikat secara psikologis pada organisasi yang memperkerjakannya melalui pendalaman tujuan organisasi, nilai-nilai, dan misinya. Bentuk komitmen ini berbeda dari komitmen afektif karena merefleksikan perasaan tugas, kewajiban dan panggilan untuk bekerja pada organisasi, namun tidak menjadikannya sebagai keterikatan emosional. Menurut Allen and Meyer (1990) karyawan dengan tingkat komitmen normatif yang tinggi merasa bahwa mereka harus berada dalam organisasi. Karyawan seperti itu dapat diharapkan untuk menunjukkan kesediaannya menempatkan tujuan organisasi diatas tujuan pribadinya.

\section{Pembentukan Komitmen Organisasi}

Menurut O'Reilley dalam Staw (1991: 299) terdapat tiga proses atau tahapan pembentukan komitmen organisasi, yakni: compliance, identification, dan internalization. Pada tahap pertama, compliance, seseorang menerima pengaruh dari orang lain, karena suatu alasan misalnya pembayaran. Tahapan yang ke dua, identification, adalah ketika seseorang menerima pengaruh orang lain dengan tujuan untuk menjaga sesuatu yang memuaskan orang lain, mendefinisikan hubungan. Orang-orang merasa bangga menjadi bagian dari perusahaan. Tahapan akhir pembentukan komitmen adalah internalization, yakni individu menemukan nilai-nilai organisasi yang secara intrinsik memberikan imbalan karena nilai-nilai organisasi sesuai dengan nilai-nilai personal. Mengingat komitmen sebagai proses internalisasi maka beragamnya budaya organisasi mencerminkan tingkatan komitmen di antara para anggotanya. Organisasi-organisasi dapat dikelompokkan berdasarkan komitmen para karyawannya. Budaya organisasi yang kuat dicirikan oleh para anggotanya yang mengidentifkasikan dirinya dengan organisasi, karena organisasi menjunjung tinggi nilai-nilai yang juga dihargai oleh para karyawan. 


\section{Faktor-faktor Komitmen Organisasi}

Kwon (2002) menyatakan bahwa komitmen afektif lebih banyak diteliti dibandingkan komitmen normative. Penelitian tentang komitmen telah dilakukan di berbagai sector ekonomi, baik sector pemerintah, swasta, sector profit dan non profit. Para pegawai di badan-badan pemerintah biasanya memiliki komitmen normative dimana mereka merasakan pekerjaan sebagai tanggung jawab moral. Hal ini menurut Kwon (2002) disebabkan karena bekerja di badan-badan milik pemerintah memiliki tingkat keamanan yang tinggi terhadap risiko kehilangan pekerjaan.

Menurut Kreitner dan Kinicki (1995 : 162) komitmen organisasi merupakan akibat yang ditimbulkan oleh kepuasan kerja. Komitmen organisasi mencerminkan adanya identifikasi individu dengan suatu organisasi dan adanya komitmen terhadap tujuan-tujuan organisasi.

Meyer and Allen, (1997), menyatakan bahwa pegawai yang memiliki hubungan yang baik dengan atasan langsungnya memiliki tingkat komitmen yang lebih tinggi. Mereka berpendapat bahwa jika pegawai memiliki komitmen yang tinggi terhadap kelompok kerjanya maka komitmen terhadap organisasi secara keseluruhan juga tinggi. Lio dalam Kwon (2002) mengatakan komitmen pekerja yang tinggi berkorelasi dengan keamanan kerja yang mereka dapatkan.

Koopman dalam Kwon (2002) mengatakan bahwa gaya manajemen dapat berpengaruh terhadap tingkat komitmen para pegawai. Para pegawai yang lebih menyukai gaya manajer mereka juga lebih menyukai organisasi, sehingga secara tidak langsung berpengaruh terhadap komitmen mereka terhadap organisasi. Nierhoff et al. dalam Kwon (2002) menyatakan bahwa budaya dan gaya yang dilakukan oleh manajemen tingkat atas (top management) memiliki korelasi yang kuat dengan tingkat komitmen para pegawai. Hubungan tersebut menunjukkan pentingnya memiliki manajer-manajer karena peranan mereka dalam organisasi secara keseluruhan.

Eisenberger et al. dalam Kwon (2002) menyatakan bahwa karyawan yang merasa diperhatikan dan mendapatkan kepedulian dari organisasi dan para manajer bukan hanya memiliki komitmen yang tinggi tetapi juga mereka lebih sadar tentang tanggung jawab pekerjaannya, memiliki keterlibatan yang tinggi, dan lebih inovatif. Para manajer dan organisasi harus memberikan imbalan dan dukungan karena pegawai yang memperoleh dukungan akan menyebabkan para karyawan lebih percaya kepada organisasi.

Dessler dalam Sutanto (1999) menyampaikan praktek-praktek kunci untuk menciptakan komitmen karyawan yang disebut dengan commitment wheel. Menciptakan komitmen memerlukan suatu perencanaan yang komprehensif, dan terdapat delapan hal yang harus dilakukan, yakni :

1. People-first values; yakni bahwa komitmen karyawan akan terwujud apabila top manajemen memiliki nilai-nilai yang mengutamakan adanya kepercayaan dan menngutamakan manusia dan menghargai keberadaannya. 
2. Double-talk; yakni adanya kemauan untuk mendengarkan dan didengarkab atau menggunakan komunikasi dua arah. Komunikasi dua arah membantu terwujudnya trust (kepercayaan).

3. Communion; yakni mendorong terwujudnya suatu perasaan keterhubungan satu sama lain di antara karyawan, rasa memiliki dan partisipasi secara keseluruhan. Hal ini akan membuat para karyawan melihat bahwa mereka adalah merupakan bagian dari suatu komunitas yang akrab dan memuaskan, dan mereka merasakan senasib.

4. Transcendental-mediation; yakni memformulasikan ideologi transendental dalam misi dan nilai-nilai, membuat suatu mekanisme untuk mengkomunikasikan nilai-nilai tersebut kepada para karyawan. Hal ini akan membuat para karyawan bertindak sebagai seorang pejuang karena melakukan sesuai dengan ideologi transendental.

5. Value-based hiring; yakni perusahaan memilih atau menseleksi karyawan yang memiliki nilai-nilai yang cocok dengan nilai-nilai perusahaan. Proses pemilihan dimulai dengan menyatakan ideologi perusahaan secara jelas, sehingga dapat disusun dan diterjemahkan dalam pernyataan-pernyataan yang konkrit, test dan pelatihan-pelatihan sehingga dibuat sebagai bagian dari proses skrining perusahaan.

6. Securitizing; yakni menyatakan secara jelas bahwa manajemen berkomitmen untuk melakukan dengan sebaik mungkin untuk mewujudkan keamanan pekerjaan (job security).

7. Hard-side rewards ; yakni menawarkan gaji di atas rata-rata dan dikombinasikan dengan insentif-insentif dan keuntungan kestensif.

8. Actualizing; yakni melibatkan karyawan, dengan tujuan untuk menjamin bahwa semua karyawan memiliki kesempatan untuk menggunakan segenap keahliannya pada pekerjaan, dan berjuang sekuat tenaga dalam menjalankan pekerjaannya.

\section{Pengaruh Komitmen Organisasi}

Robbin (2003:94) menyatakan bahwa tingkat komitmen organisasi seorang individu berhubungan terbalik dengan pengunduarn diri karyawan. Komitmen organisasi merupakan indikator yang lebih baik karena hal itu merupakan tanggapan yang lebih global dan awet terhadap organisasi secara keseluruhan dibandingkan kepuasan kerja. Seorang karyawan mungkin tidak puas dengan pekerjaan tertentu dan menganggapnya sebagai kondisi sementara, namun bukan tidak puas dengan organisasi secara keseluruhan.

Komitmen yang rendah memiliki dampak negatif terhadap kinerja karyawan, sebagaimana dikemukakan oleh Koch dalam Sopiah (2008:166) yang menyatakan bahwa karyawan yang berkomitmen rendah akan berdampak pada turn-over, tingginya absensi, meningkatnya kelambanan kerja dan kurangnya intensitas untuk bertahan. Sementara Steers dalam Sopiah (2008:166) menyatakan bahwa komitmen yang rendah berakibat pada rendahnya kualitas kerja dan kurangnya loyalitas pada perusahaan. Near dan Jansen dalam Sopiah (2008:166) menyatakan bahwa komitmen karyawan yang rendah akan memicu perilaku karyawan yang kurang baik, misalnya tindakan yang berdampak pada 
menurunnya reputasi organisasi, kehilangan kepercayaan dari klien dan dampak lebih jauh adalah penurunan laba perusahaan.

\section{Kepemimpinan dan Komitmen Organisasi}

Peranan kepemimpinan terhadap komitmen personil/pegawai tidak dapat dipisahkan. Kepemimpinan merujuk pada kemampuan seseorang untuk mempengaruhi orang lain atau kelompok untuk berpola sikap dan berpola perilaku tertentu dalam rangka dan untuk mencapai suatu tujuan. Seseorang yang mempunyai kemampuan untuk mempengaruhi kelompok disebut sebagai Pemimpin. Setiap organisasi apapun jenisnya pasti membutuhkan dan memiliki pimpinan. Pemimpin adalah orang pertama yang bertanggungjawab untuk mengarahkan jalannya perusahaan termasuk membangun motivasi dan komitmen pegawai. Kepemimpinan merupakan interaksi antara pihak yang memimpin dengan pihak yang dipimpin. Hubungan ini berlangsung melalui interaksi personal yang saling mendorong untuk mencapai tujuan, baik tujuan organisasi maupun tujuan individu/personal. Menurut Northouse (2004:5), leadership is a process whereby an individual influence a group of individuals to achieve a common goal. Kepemimpinan adalah perilaku seseorang yang memimpin kegiatan suatu kelompok dalam rangka mencapai tujuan atau sasaran bersama (shared goal). Tegasnya, kepemimpinan merupakan proses memberi arti terhadap usaha kolektif yang mengakibatkan kesediaan seseorang (komitmen) untuk melakukan usaha dalam rangka mencapai tujuan.

Menurut Robbins and Judge (2008:176), terdapat beberapa konsep kepemimpinan efektif sesuai dengan kondisi lingkungan, yakni pendekatan karakteristik pribadi (trait theory), pendekatan perilaku (behavior theory), pendekatan model dan kemungkinan (contingency theory), dan pendekatan kontemporer (modern theory). Pendekatan karakteristik pribadi merupakan pendekatan atau teori klasik dalam melihat kepemimpinan. Menurut pendekatan ini, kemampuan kepemimpinan seseorang dapat dilihat dan ditentukan oleh karakteristik orang tersebut. Seorang pemimpin mempunyai ciri-ciri yang tidak dipunyai oleh mereka yang bukan pemimpin, mulai dari ciri kepribadian, sosial, fisik, hingga ciri intelektual. Terdapat enam ciri yang membedakan pemimpin dan bukan pemimpin, yakni ambisi dan energi, hasrat untuk memimpin, kejujuran dan integritas, kepercayaan diri, kecerdasan, dan pengetahuan yang relevan dengan pekerjaan.

Berbeda dengan pendekatan karakteristik atau ciri-ciri pribadi, menurut pendekatan atau teori perilaku, kemampuan kepemimpinan seseorang ditentukan oleh perilaku spesifik yang bersangkutan. Faktor perilaku tersebut merupakan hal yang membedakan pemimpin dari bukan pemimpin. Bila dalam teori ciri-ciri pribadi seorang pemimpin dihasilkan dengan cara menyeleksi orang yang tepat bagi jabatan formal dalam kelompok atau organisasi yang menuntut kepemimpinan; dalam menurut pendekatan perilaku; kemampuan kepemimpinan diperoleh dengan cara mengajarkan kemimpinan serta merancang programprogram yang menanamkan pola perilaku ke dalam diri individu yang berminat untuk menjadi pemimpin yang efektif. 
Pendekatan lain adalah modern theory yang salah satu model yang dikembangkan adalah kepemimpinan transformasional (Northouse, 2004: 70). Model ini diimpelementasikan dengan jalan mentransformasikan nilai-nilai, kepercayaan, dan ransangan intelektual, serta kebutuhan para anggota; serta mempunyai beberapa karakteristik, yakni charisma dengan memberikan visi dan misi, menanamkan kebanggaan, memperoleh respek dan kepercayaan; inspirations dengan memberikan inspirasi kepada bawahan dengan jalan mengkomunikasikan harapan yang tinggi, menggunakan lambang-lambang untuk memfokuskan upaya, mengungkapkan maksud-maksud penting dengan cara yang sederhana; intellectual stimulation dengan memberikan rangsangan intelektual dengan jalan mengembangkan kecerdasan, rasionalitas, dan memecahkan masalah secara teliti, sistematis, dan ilmiah; serta individual consideration dengan memberikan perhatian dan pertimbangan secara individual dengan jalan memberikan perhatian pribadi, memperlakukan setiap karyawan secara individual, memberikan latihanlatihan serta memberikan nasehat-nasehat secara individu.

Apapun pendekatannya, mempengaruhi orang lain untuk berkontribusi dan atau melakukan sesuatu untuk kepentingan organisasi merupakan esensi kepemimpinan. Fungsi utama kepemimpinan adalah menumbuhkan komitmen dengan jalan mempengaruhi baik pemikiran maupun pola perilaku anggota organisasi. Banyak metode dapat dilakukan untuk mempengaruhi serta membangun komitmen anggota, yakni melalui argumentasi logis dan bukti faktual untuk mempersuasi bahwa suatu kegiatan adalah masuk akal dan dapat mencapai sasaran yang telah ditetapkan bersama; membangunkan entusiasme target dengan menunjuk kepada nilai-nilai, ideal, dan aspirasi target; membuka peluang partisipasi target dalam melaksanakan strategi, aktiviutas, atau perubahan; menggunakan pujian, rayuan, perilaku ramah tamah, atau perilaku yang membuat target berada dalam keadaan yang menyenangkan; menggunakan perasaan mengenai kesetiaan dan persahabatan; menawarkan balas budi, serta menjanjikan keuntungan tertentu apabila suatu target dapat dicapai. Metode tersebut merupakan kegiatan yang secara rutin dan setiap saat harus dilakukan seorang Pemimpin. Kepemimpinan transformasional memotivasi anggota serta membangun komitmen dengan meningkatkan tingkat kesadaran anggota mengenai pentingnya tujuan yang hendak dicapai; membuat anggota melakukan sesuatu melebihi yang mereka harapkan; serta menggerakan anggota agar fokus pada kebutuhan lebih tinggi (Northouse, 2004:173).

\section{SIMPULAN}

Setiap perusahaan dibangun dari dua macam modal yakni financial capital dan intellectual capital. Intellectual capital terdiri dari human capital, structural capital, dan customer capital. Human capital dipengaruhi oleh 2 dimensi yaitu, kuantitatif (tangible) yang lebih melihat jumlah personil yang terlibat dalam keseluruhan proses dan operasi perusahaan, serta dimensi kualitatif (intangible) yang terdiri dari kompetensi dan komitmen. Kepemimpinan berpengaruh terhadap human capital dengan komitmen sebagai variabel intervening. Dengan pola 
kepemimpinan yang efektif akan mempengaruhi orang lain untuk mempunyai komitmen yang tinggi pada organisasi. 


\section{DAFTAR PUSTAKA}

Allen and Meyer, 2001, A Three Component Conceptualization of Organizational Commitment, Human Resources Management Review, Vol.1, No.1, 1991 pp. 61-89

Edvinsson, L., dan Malone, M.S., 1997, Intellectual Capital: Realizing Your Company's True Value by Finding its Hidden Brain Power, New York: Harper Business.

Greenberg, J., and Baron, A.B. 2003. Behavior in Organization. 8th Ed. NJ: Prentice Hall.

Kaplan, R.S, dan David P.N., 1996, The Balanced Scorecard: Translating Strategy into Action, Massachusetts: Harvard Business School Press.

Nahapiet, J. dan S. Ghoshal, 1998, Social Capital, Intellectual Capital, and the Organizational Advantage, Academy of Management Review, 1998, Vol. 23, NO. 2: 243-266.

Northouse, Peter G. 2004. Leadership: Theory and Practice. 3td Ed, Sage Publications, Inc.

Olve, N.G., J. Roy, dan M. Wetter, 1999, Performance Drivers: A Practical Guide to Using the Balanced Scorecard, John Wiley \& Sons.

Porter, L.W., et al., 1974, Organizational Commitment, Job Satisfaction, and Turnover among Psychiatric Technician, Journal of Applied Psychology, No, 59: 603-609.

Porter, M.E., 1993, Competitive Advantage, Collier Macmillan Publishers.

Robbins, S.P., 1990, Organization Theory: Structure, Design, and Applications, 3td Ed, New Jersey: Prentice-Hall, Inc.

Robbins, P Stephen, Judge, A Timothy, 2008, Essentials of Organizational Behavior, 9th edition, Pearson Prentice Hall, England.

Schermerhorn, Hunt, dan Osborn, 1995, Basic Organizational Behavior, John Wiley \& Sons

Stewart, Th. A, 1997, Intellectual Capital, London: Nicholas Brealy Publishing.

Sveiby, K.E., 1998, Intellectual Capital: Thingking Ahead, Australian CPA, June: $18-21$.

Ulrich, D., 1998, Intellectual Capital = Competence x Commitment, Sloan Management Rewiew, Winter 1998: 15 - 26.

Walker, Diana Ch., 2001, Exploring the Human Capital Contribution to Productivity, Profitability, and the Market Evaluation of the Firm, Dissertation, Webster University. 